\title{
Maria Sebagai Model Ketaatan Menurut Luk. 1:26-38 dan Lumen Gentium
}

\author{
Irvan Prasetya ${ }^{\mathrm{a}, 1}$ \\ R.F. Bhanu Viktorahadi ${ }^{b, 2}$ \\ Program Magister Ilmu Teologi, Fakultas Filsafat Universitas Katolik Parahyangan Bandung, Indonesia ${ }^{a}$ \\ Program Studi Ilmu Filsafat, Fakultas Filsafat Universitas Katolik Parahyangan Bandung Indonesia ${ }^{\mathrm{b}}$ \\ irvanprasetya94@gmail.com ${ }^{1}$ \\ torahadi@unpar.ac.id ${ }^{2}$
}

\begin{tabular}{|c|c|}
\hline & Abstract \\
\hline $\begin{array}{l}\text { KEYwORDS: } \\
\text { Maria } \\
\text { Lumen Gentium } \\
\text { Hamba Tuhan } \\
\text { Ketaatan } \\
\text { Lukas }\end{array}$ & $\begin{array}{l}\text { The current paper aims to highlight the unrestricted obedience by } \\
\text { Mary when declaring herself 'the handmaid of the Lord' and when } \\
\text { demanding that the divine will would be accomplished in her, just } \\
\text { when she agrees to be chosen by God as virginal mother of his } \\
\text { divine Son incarnate. The elements of the unrestricted obedience are } \\
\text { drawn out of the text of Luke 1:26-38 using the Narrative Analysis } \\
\text { Method. Apart from that, these elements were also sought and found } \\
\text { by analyzing the Second Vatican Council's Dogmatic Constitution } \\
\text { 'Lumen Gentium', especially the section on the Church's view of } \\
\text { Mary (53-69). Looking to Mary as an example, Christian learn to } \\
\text { obey God in the path of faith and finds the values that lead him or } \\
\text { her through the paths of the good Christian life. }\end{array}$ \\
\hline
\end{tabular}

\section{PENDAHULUAN}

Walaupun sejumlah ahli berpandangan bahwa Markus adalah penginjil pertama yang yang memberi perhatian secara khusus kepada Maria ${ }^{1}$, episode penyampaian warta dari Malaikat Gabriel kepada Perawan Maria di Nazaret, Galilea bahwa ia akan mengandung dan melahirkan Putera Allah

\footnotetext{
Philip J. Donnelly, "The Perpetual Virginity of the Mother of God," ed. Juniper B. Carol, Mariology vol. 2 (Milwaukee: The Bruce Publishing Company, 1957) 254.
}

hanya terdapat dalam Injil menurut Lukas (Luk.1:26-38). Tradisi Gereja menyebut episode tersebut sebagai 'Pewartaan Kabar Sukacita kepada Maria’ yang di dalamnya terdapat gagasan Allah yang setia pada perjanjian-Nya ${ }^{2}$ untuk menyelamatkan manusia. Selama berabad-abad perhatian 
pada peristiwa 'kabar sukacita' itu telah menghasilkan sejumlah besar tulisan dari segala jenisnya. Antara lain, menemukan reka ulang episode ini pada Perjanjian Lama dalam Perjanjian Baru $^{3}$ dan penelitian dogmatis. Akan tetapi, tulisan-tulisan yang membahas secara unik dan khas terkait kualitas pribadi, terutama sikap taat yang dimanifestasikan Maria dalam episode ini sebagai model karakter umat beriman masih terbatas. ${ }^{4}$

Secara spesifik penelitian ini bertujuan menyoroti ketaatan tak terbatas yang diungkapkan Maria saat mengungkapkan dirinya sebagai 'hamba Tuhan' dan saat membiarkan kehendak Ilahi terjadi secara penuh dalam dirinya. Maria mengungkapkan ketaatan tak terbatas itu saat menjadi pilihan Allah sebagai Bunda Perawan dari Putra-Nya yang menjelma menjadi manusia. Dengan ketaatan dan kerendahan hatinya, Maria memberikan Juru Selamat kepada bangsa Israel dan umat manusia. ${ }^{5}$ Untuk sampai pada tujuan itu, penelitian ini memiliki dua rumusan permasalahan. Pertama, bagaimana narasi 'kabar sukacita' menunjukkan unsur-unsur ketaatan Maria pada kehendak Ilahi? Kedua, bagaimana unsur-unsur ketaatan tersebut dapat diaplikasikan sebagai model umat beriman.

Guna menjawab permasalahan itu penelitian ini menggunakan episode atau narasi 'kabar sukacita' (Luk.1:26-38) sebagai subjek penelitian. Pilihan jatuh pada Injil menurut Lukas, dengan alasan

Goppelt Leonhard, Typos. The Typological Interpretation of the Old Testament in the New (Grand Rapids, MI.: Wm. B. Eerdmans Publishing Co., 1939) xiv.

$4 \quad$ José María Salvador González, "The Virgin Mary as a Model of Obedience in the Patristic Tradition and Her Representation in the Late Medieval Iconography of the Annunciation," Social Sciences and Humanities Journal (SSHJ), Vol. 10, No. 8, August 2015: 1-23 (3).

John McHugh, The Mother of Jesus in the New Testament (New York: Doubleday, 1975) 80. penginjil ini memberikan gambaran yang paling utuh dan simpatik terhadap Maria. Antara lain, suasana batinnya saat menerima kabar sukacita. ${ }^{6}$ Dengan menggunakan Metode Analisis Naratif, penelitian ini menjawab permasalahan pertama, yaitu bagaimana menemukan unsur-unsur ketaatan Maria dalam narasi itu. ${ }^{7}$ Penelitian ini menggunakan Metode Analisis Naratif karena tulisan-tulisan Lukas lebih berbentuk narasi.

Sebagai salah satu dari sejumlah metode yang ada dalam ranah tafsir teks Kitab Suci, analisis naratif termasuk salah satu bentuk analisis literal yang meneliti teks Kitab Suci seturut aspek kesusastraan. ${ }^{8}$ Metode analisis naratif merupakan suatu pendekatan untuk memahami dan mengkomunikasikan pesan alkitabiah yang dalam bentuk narasi dan kesaksian personal, sesuatu yang merupakan salah satu ciri khas teks Kitab Suci dan model komunikasi antar-manusia. ${ }^{9}$ Dalam konteksnya, pewartaan iman Kristen pada dasarnya sama dengan rangkaian katekese yang muncul dalam bentuk narasi. Bahkan, hampir sepertiga Kitab Suci terdiri atas narasi-narasi. ${ }^{10}$

Sedangkan untuk menjawab permasalahan kedua, penelitian ini akan menggunakan metode analisis kritis. Metode ini menganalisis sejumlah teks ajaran dan tradisi Gereja. Secara spesifik, ajaran yang digunakan berasal dari Konstitusi Dogmatis tentang Gereja 'Lumen Gentium'. Dokumen

\footnotetext{
Lucien Deiss, Mary: Daughter of Sion (Collegeville, Minn.: Liturgical Press, 1972) 129.

7 Penelitian ini menggunakan Metode Analisis Naratif karena tulisan-tulisan Lukas lebih berbentuk narasi berdasarkan Tom Jacobs, Lukas. Pelukis Hidup Yesus (Yogyakarta: Kanisius, 2006) 27.

8 A.A. Sitompul dan U. Beyer, Metode Penafsiran Alkitab Uakarta: BPK Gunung Mulia, 1973) 50.

$9 \quad$ Komisi Kitab Suci Kepausan, Penafsiran Alkitab dalam Gereja (Yogyakarta: Kanisius, 2003) 57.

10 Shimon Bar-Efrat, Narrative Art of Bible (Sheffield: Sheffield Academic Press, 1997) 9.
} 
Konsili Vatikan II ini dipilih karena memuat secara khusus pernyataan Gereja tentang Maria. Menurut Lumen Gentium, Maria merupakan sosok yang kehadirannya telah dibicarakan dan dinubuatkan sejak Perjanjian Lama. Secara implisit Perjanjian Lama menyebut Maria sebagai perempuan yang akan melahirkan Penebus (LG 55). Maria menjadi pilihan Allah karena sejak awal tidak tercemar noda dosa. Kesadaran inilah yang memampukan Maria untuk memutuskan secara bebas dalam ungkapan kesepakatannya, dengan mengatakan 'ya' pada kehendak Allah, serta siap menjadi ibu Penyelamat (LG 56).

\section{NARASI 'KABAR SUKACITA' DALAM}

LUK. $1: 26-38$

Walaupun tetap dapat dibaca sebagai suatu bentuk narasi, peristiwa 'kabar sukacita' juga mengindikasikan pola panggilan dan perutusan seorang nabi. ${ }^{11}$ Terkait dengan indikasi ini, narasi panggilan Musa (Kel.3:114) dan Gideon (Hak.6:11-24) ${ }^{12}$ dapat menjadi bandingannya. Perbandingan itu sekaligus mengungkapkan bahwa narasi ini sangat memperhitungkan peran Roh Kudus dalam panggilan dan perutusan Maria. Peran Roh Kudus ini memiliki pengaruh besar pada tanggapan yang diberikan Maria terhadap kehendak Ilahi.

Narasi 'kabar sukacita' dalam teks Luk.1:26-38 terjalin seturut alur atau plot yang membangun sistematika narasi dengan menyusun suatu konfigurasi kejadiankejadian dalam suatu kaitan sebab-akibat sehingga menjadi suatu proses kronologis

\footnotetext{
B.E. Reid, "An Overture to the Gospel of Luke," Theology and Mission 39,6 (2012): 428-434 (428-429).

12 M. Navarro Puerto, María, la mujer. Ensayo psicológico bíblico (Madrid: Claretianas, 1987) 197.
}

sampai pada puncaknya. ${ }^{13}$ Berdasarkan alur tersebut, struktur naratif teks Luk.1:26-38 ${ }^{14}$ adalah sebagai berikut.

Introduksi karakter narasi (26-27)

A Malaikat masuk (28a)

B Salam (28b)

C Pertanyaan Maria (29) dan

Jawaban Malaikat (30-33)

[tentang makna salam]

C' Pertanyaan Maria (34) dan

JawabanMalaikat (35-37)

[tentang keraguan]

B' Tanggapan Maria (38a)

A' Malaikat keluar (38b)

Struktur naratif membentuk suatu struktur khiastik yang terjadi setelah adanya pengenalan karakter, yaitu Allah, Malaikat Gabriel, dan Maria. Dalam struktur khiastik ini, Allah menghilang dari posisiNya sebagai salah satu karakter. Malaikat Gabriel mengambil alih peran Allah untuk menyampaikan pesan atau sabda-Nya. Untuk membangun struktur khiastik itu, struktur naratif teks menunjukkan sejumlah unsur dalam teks yang memiliki kesejajaran atau paralel. Salah satunya adalah salam dari Malaikat Gabriel (Luk.1:28b) dengan tanggapan Maria (Luk.1:38a). Kesejajaran kedua bagian itu menunjukkan keterkaitan antara sapaan Ilahi dengan tanggapan bebas yang muncul dari diri manusia bernama Maria. Narasi 'kabar sukacita' itu melukiskan bahwa Allah menyampaikan pesan kepada Maria melalui Malaikat Gabriel. Di sini

Daniel Marguerat and Yvan Bourquin, How to Read Bible Stories. An Introduction to Narrative Criticism (London: SCM Press, 1999) 41.

14 Struktur ini berbeda dan merupakan sebuah bentuk struktur alternatif dari yang telah ditulis oleh Huub Welzen [cf. Huub Welzen, "Exegetical Analysis and Spiritual Readings of the Story of the Annunciation (Luke 1:26-38)," Acta Theologica Supplementum 15, 2011: 21-36 (29)]. 
Gabriel bertindak sebagai utusan Allah ${ }^{15}$ untuk pergi ke sebuah dusun yang sangat penting di Galilea. ${ }^{16}$ Saat menyapa Maria melalui Malaikat Gabriel, Allah tidak hanya menyapa Maria secara personal dan individual. Dengan sapaan itu, Allah juga menyapa seluruh umat manusia. Sapaan itu menjadi ungkapan bahwa Allah akan datang untuk berdiam di antara bangsa Israel untuk menyatakan bahwa keselamatan mereka sudah dekat. Oleh karena itu, salam melalui perantaraan Malaikat Gabriel itu menjadi ajakan bagi umat manusia untuk bersukacita atas keselamatan yang akan segera tiba.

Salam ini merujuk pada nubuat Zakaria dalam Perjanjian Lama. "Bersorak-sorailah dan bersukarialah, hai puteri Sion, sebab sesungguhnya Aku datang dan diam di tengah-tengahmu, demikianlah firman TUHAN" (Zak.2:10). Kabar sukacita yang diterima Maria memenuhi janji Allah yang terungkap dalam nubuat Zakaria itu. Dengan menggunakan sudut pandang nubuat Zakaria itu, Maria diidentifikasikan sebagai puteri Sion. Sedangkan Yesus, Putera yang akan dilahirkannya diidentifikasikan sebagai Allah yang akan berdiam di tengah-tengah umat manusia. ${ }^{17}$ Rujukan pada nubuat Zakaria menjadi bukti adanya indikasi narasi 'kabar sukacita' ini memiliki pola panggilan dan perutusan nabi. Akan tetapi, sejumlah unsur lainnya membuat narasi ini juga memiliki keunikan, terutama dalam sebutan yang diberikan Malaikat Gabriel kepada Maria saat menyampaikan salam.

\footnotetext{
5 Solomon Schechter, Ludwig Blau, and Emil G. Hirsch, "Gabriel

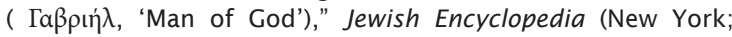
London: Funk and Wagnalls Company, 1901) 540-543.

16 Joseph A. Fitzmyer, The Gospel According to Luke I-IX. AB 28 (Garden City: Doubleday, 1981) 343.

17 Joseph Cardinal Ratzinger and Hans Urs von Balthasar, Mary: The Church at the Source (San Francisco: Ignatius Press, 2005) 64-65.
}

Saat menyampaikan kabar sukacita kepada Maria, Malaikat Gabriel tidak memanggilnya dengan nama 'Maria'. Malaikat Gabriel memanggilnya dengan sebutan 'hai engkau yang dikaruniai' (Luk.1:28b). Dengan menganalisis sebutan terhadap Maria ini, sejumlah ahli berpendapat bahwa Malaikat Gabriel tidak memanggil Maria dengan nama duniawinya ('Maria'). ${ }^{18}$ Dalam peristiwa itu Gabriel memanggil atau menyapa Maria dengan sebutan Ilahi ('engkau yang dikaruniai'). Sapaan itu mengungkapkan bahwa Maria senantiasa mendapat perhatian khusus dari Allah karena ungkapan 'yang dikaruniai' mengungkapkan kasih Allah terhadap Maria. ${ }^{19}$ Dengan kata lain, dengan memeroleh saapan itu Maria menjadi pribadi yang mendapat perhatian penuh dari Allah. ${ }^{20}$ Kasih Allah terhadapnya itu menjadi persiapan Maria untuk masuk dalam cara hidup sebagai seorang perawan dalam makna bahwa dirinya hanya tersedia bagi kehendak Allah. Sebagai perawan keseluruhan hidup Maria menjadi pengembangan atau perluasan rahmat Allah bagi umat manusia. ${ }^{21}$ Selain itu, bentukan kata dalam teks asli berbahasa Yunani juga mengungkapkan bahwa karunia yang diterima Maria bersifat tetap atau permanen. ${ }^{22}$

Yang juga perlu diperhatikan adalah status sosial Maria saat mengalami peristiwa kabar sukacita. Teks Kitab Suci (Luk.1:27) menjelaskan bahwa Maria adalah 'seorang perawan yang bertunangan dengan seorang

\footnotetext{
18 Thomas G. Weinandy, Jesus Becoming Jesus: A Theological Interpretation of the Synoptic Gospels (Washington, D.C: Catholic University of America Press, 2018) 7-8.

19 Benedict XVI, Maria: On the Mother of God (San Francisco: Ignatius Press, 2009) 51-52.

20 Joseph Cardinal Ratzinger and Hans Urs von Balthasar, op.cit., 68.

21 Ignace de La Potterie, Mary in the Mystery of the Covenant (New York: Alba House, 1992) 4-5.

22 I.H. Marshall, The Gospel of Luke: A Commentary on the Greek Text (Exeter: Paternoster; Grand Rapids: Eerdmans, 1978) 65.
} 
bernama Yusuf dari keluarga Daud'. Secara budaya dan tradisi teks tersebut mengasumsikan bahwa Maria saat itu adalah seorang gadis muda ${ }^{23}$ dalam usia menikah. ${ }^{24}$ Dari sudut pandang budaya, jika sudah bertunangan, seorang gadis muda memiliki satu tahun untuk menyiapkan pakaian pengantinnya. ${ }^{25}$ Dalam usia dan periode tersebut masuk akal jika muncul keraguraguan dalam dirinya untuk mengambil keputusan besar lain bagi hidupnya, mengingat Maria saat itu sudah bertunangan dengan Yusuf. ${ }^{26}$ Keraguan dan kecemasan Maria untuk menerima kehendak Allah mendapat jaminan dari Allah.

Malaikat Gabriel mengungkapkan jaminan itu dalam kepastian bagi Maria bahwa Roh kudus akan turun ke atas dirinya. "Roh Kudus akan turun atasmu dan kuasa Allah yang Mahatinggi akan menaungi engkau" (Luk.1:35a). Roh Kudus turun dan tinggal diam dalam diri Maria. Ungkapan ini merujuk pada tiang awan turun di pintu kemah tempat Musa berdiam. "Apabila Musa masuk ke dalam kemah itu, turunlah tiang awan dan berhenti di pintu kemah dan berbicaralah TUHAN dengan Musa di sana" (Kel.33:9). Dengan ungkapan itu, Maria menjadi kemah suci (tabernakel) tempat Allah berdiam, berfirman, dan bertindak demi keselamatan manusia. ${ }^{27}$ Selain menjadi tabernakel tempat Allah bertemu dengan umat-Nya, ${ }^{28}$ dengan merujuk kehadiran Allah dalam Tabut Perjanjian

23 Joel B. Green, "The Social Status of Mary in Luke 1,5-2,52: A Plea for Methodological Integration," Biblica 73 (1992): 458471(464-465).

24 Elizabeth A. Johnson, Dangerous Memories: A Mosaic of Mary in Scripture: Drawn from Truly Our Sister (New York; London: Continuum, 2006) 14.

25 Hayyim Schauss, The Lifetime of a Jew Throughout the Ages of Jewish History (New York: Union of American Hebrew Congregations, 1950) 154.

26 Rudolf Bultmann, History of the Synoptic Tradition, trans. John Marsh (Oxford: Basil Blackwell, 1963) 295.

27 William Brown, The Tabernacle: Its Priests and Its Services (Peabody, Massachusetts: Hendrickson Publishers, 1996) 3.

28 Ralph W. Harris, Old Testament Types (Springfield, MO.: Gospel Publishing House, 1965) 39.
(Kel.25:22), Maria sekaligus menjadi Tabut Perjanjian yang hidup, terutama karena telah mengandung dan melahirkan Yesus, Putera Allah. ${ }^{29}$ Dengan kata lain, Maria adalah Tabut Perjanjian yang baru, ${ }^{30}$ tempat ditemukannya Allah yang menyelamatkan. ${ }^{31}$

Kehadiran Roh Kudus itu menjadikan Maria tempat tinggal Allah di dunia. Berkat kehadiran Roh Kudus itu pula, Maria menjadi bagian integral misteri keselamatan yang sangat penting. Dalam Gereja, Maria memang bukan pusat. ${ }^{32}$ Akan tetapi, walaupun bukan pusat, Maria memiliki peran yang penting. Roh Kudus ini memampukan Maria berperan penting dengan berpartisipasi secara aktif dan penuh dalam rencana penyelamatan Allah. Roh Kudus itu memberi jaminan supaya Maria sungguh dapat menjadi sarana untuk merealisasikan rencana karya penyelamatan Allah bagi seluruh manusia. ${ }^{33}$ Dengan deskripsi itu, narasi 'kabar sukacita' ini memuat untuk pertama kalinya bentuk kerja sama atau kolaborasi partisipatif antara Allah dengan makhluk ciptaan-Nya dalam melaksanakan rencana karya penyelamatan-Nya. Tawaran kerja sama itu mendapat tanggapan dari Maria dalam wujud kesediaan diri. Kesediaan diri ini pada gilirannya menjadi iman yang aktif. Iman ini mencakup kesiap-sediaan dan keyakinan penuh untuk membiarkan Allah mengerjakan rencana karya keselamatan melalui dirinya. ${ }^{34}$

\footnotetext{
29 Joseph Cardinal Ratzinger and Hans Urs von Balthasar, op.cit., 65.

30 Joseph Cardinal Ratzinger, Daughter Zion: Meditations on the Church's Marian Belief, trans. John M. McDermott SJ (San Francisco: Ignatius Press, 1983) 43.

31 C.G. Álvarez, María Discípula de Jesús, y mensajera del Evangelio (Bogotá, Colombia: San Pablo. 2007) 60.

32 Leo Scheffcyk, Maria, Crocevia della fede cattolica (Pregassona, Lugano: Eupress, 2002) 44-46.

33 Jacques Bur, How to Understand the Virgin Mary (London: SCM Press LTD, 1994) 8-9.

34 Jean Galot, Mary in the Gospel (Westminster, Maryland: The Newman Press, 1965) 50.
} 


\section{KESEDIAAN MARIA}

Tanggapan Maria atas jaminan Allah yang disampaikan melalui Gabriel menemukan klimaks atau puncaknya dalam persetujuannya terhadap kehendak Allah. "Sesungguhnyaakuiniadalah hambaTuhan; jadilah padaku menurut perkataanmu itu" (Luk.1:38). Tanggapan itu menunjukkan kesadaran Maria akan posisinya di hadapan Allah. Kesadaran itu dilandasi dengan iman yang kuat dan penyerahan diri yang total kepada Allah sehingga menghantarkan Maria untuk menerima tugas perutusan yang diberikan Allah secara sukarela. Artinya, Maria tidak mau bersikap lain kecuali setuju terhadap sapaan dan panggilan Allah tersebut. Jawaban 'Ya' yang diungkapkan Maria menunjukkan kerelaan Maria untuk menyerahkan kebebasan yang dimilikinya dan dipersembahkan kepada Allah. Melalui penyerahan diri inilah Maria dihantar kepada kekudusan yang istimewa. ${ }^{35}$ Kenyataan lain yang mendukung ketersediaan Maria adalah bahwa ia seorang perawan. Di luar makna fisik, secara psikologis perawan menunjukkan ketersediaan. Kondisi perawan mengungkapkan kondisi murni, polos, dan tidak berpretensi untuk melakukan pemberontakan melawan kehendak Allah sebagaimana telah dinubuatkan Yesaya. "Tuhan ALLAH telah membuka telingaku, dan aku tidak memberontak, tidak berpaling ke belakang" (Yes.50:5).

Maria mengungkapkan kesadaran diri sebagai manusia di hadapan Allah dengan menyebut dirinya sebagai 'hamba Tuhan'. Ungkapan diri Maria sebagai 'hamba Tuhan' mendapat perhatian dari sejumlah penafsir. Dari sejumlah catatan para penafsir atas ungkapan 'hamba Tuhan' ini ditemukan

35 Eddy Kristiyanto, Maria dalam Gereja (Yogyakarta: Kanisius, 1987) 27-29. unsur-unsur ketaatan yang ditunjukkan Maria. Istilah 'hamba' yang digunakan Maria dalam teks bahasa Yunani adalah 'doulos'. Istilah 'doulos' dapat diterjemahkan sebagai 'hamba' atau 'pelayan'. Secara lebih spesifik istilah itu juga dapat diterjemahkan sebagai 'hamba atau pelayan perempuan'. ${ }^{36}$ Maria menjadi hamba atau pelayan yang sejati karena Allah sendiri yang memilihnya. ${ }^{37}$

Akan tetapi, ada yang tidak sepakat dengan pemaknaan 'doulos' sebagai pelayan atau hamba. Alasannya, sekadar menerjemahkan istilah itu sebagai 'hamba atau 'pelayan' secara umum akan mengaburkan makna otentiknya dalam konteks masyarakat Palestina pada abad pertama. Makna yang lebih kontekstual untuk wilayah dan periode itu adalah 'pekerja'. Dapat juga istilah itu bermakna 'alat bantu yang hidup' (organon). 'Pekerja' memiliki peran yang spesifik. Perannya adalah menjalankan tugas untuk keuntungan tuannya. Dengan kata lain, seorang pekerja tidak dapat bekerja seturut rencana atau kemauannya sendiri. Ia bekerja seturut kehendak tuannya. Dalam konteks Maria, ungkapannya sebagai 'hamba Tuhan' menegaskan bahwa sejak itu segala pekerjaannya terjadi berdasarkan perintah atau kehendak Allah. ${ }^{38}$

Unsur ketaatan Maria semakin nampak dalam ungkapan selanjutnya. "Terjadilah padaku menurut perkataanmu itu" (Luk.1:38). Dalam teks Kitab Suci berbahasa Yunani ungkapan 'terjadilah' menggunakan bentukan 'génoito'. Akar katanya adalah 'ginomai'. 39 'Génoito' adalah

\footnotetext{
$36 \quad$ Max Zerwick and Mary Grosvenor, A Grammatical Analysis of the New Testament (Roma: Editrice Pontificio Istituto Biblico, 1996) 172.

37 Xavier Leon-Dufour, Dizionario di Teologia Biblica (Genova: Casa Editrice Marietti S.p.A., 2002) 1193-1194.

38 Ceslas Spicq, Theological Lexicon of the New Testament, James D. Ernest (trans.) (Peabody, Massachusetts, 1994) 380-383.

39 Carlo Buzzetti, Dizionario Base del Nuovo Testamento. Greco-
} 
bentukan aoris optatif. Bentukan Aoris tidak memperhitungkan waktu dalam makna lampau, kini, atau masa depan. Bentukan ini juga tidak memperhitungkan durasi waktunya. Yang menjadi perhatiannya adalah suatu titik waktu yang partikular atau khusus saat satu peristiwa berlansung. Dengan kata lain, aoris seperti seseorang memandang dengan menggunakan teleskop ke arah satu titik tertentu. Sebagai bandingan untuk 'terjadilah' yang diungkapkan Maria, kata 'jadilah (kehendak-Mu)' pada teks doa Bapa Kami versi penginjil Matius (Mat.6:10) memiliki keserupaan. ${ }^{40}$ Kedua ungkapan '(ter)jadilah' itu sama-sama menunjukkan adanya upaya melaksanakan kehendak secara presisi seturut kehendak orang (tuan) yang memberi perintah atau yang berkehendak.

Bentukan kata 'terjadilah' dalam teks Yunani tidak hanya aoris, tetapi aoris optatif. Bentukan optatif menunjukkan ekspresi suasana hati ditambah kehendak atau hasrat yang kuat. ${ }^{41}$ Dengan kata lain, kehendak Maria supaya dapat melaksanakan kehendak Allah yang disampaikan melalui Malaikat Gabriel itu sungguh-sungguh datang dari kedalaman hatinya untuk secara total alias tidak setengah-setengah. Dengan mengungkapkanitu, Maria sungguh-sungguh melepaskan segala kehendak pribadinya, sekaligus menempatkan kehendak Allah sebagai satu-satunya kehendak yang harus dilaksanakannya secara total.

Keutamaan lain yang turut mendukung kesediaan Maria melaksanakan kehendak Allah adalah kerendahan hatinya. Kerendahan hati itu terungkap dalam

Italiano (Roma: Società Biblica Britannica e Forrestiera, 2001) 32.

40 Carlo Rusconi, Vocabolario del Greco del Nuovo Testamento (Bologna: Edizione Dehoniane, 1997) 74-75.

$41 \quad$ Max Zerwick and Mary Grosvenor, op.cit., 172. kesediaannya menanggung aneka macam risiko dan beban yang akan diterimanya saat sepakat dengan kehendak Allah. Dengan rendah hati Maria membuka dan menyediakan ruang dalam dirinya untuk kehadiran Allah. Pèire de Joan-Oliu OFM (1248-1298) seorang teolog dan filsuf Fransiskan yang memiliki gagasan radikal tentang penghayatan kemiskinan religius menyatakan bahwa ketaatan Maria sangat bergantung pada kerendahan hatinya yang berasal dari jiwa terdalamnya.

"Maria memiliki kualitas jiwa yang sungguh-sungguh terpanggil dan terarah kepada realitas sorgawi yang lebih tinggi sekaligus lebih dalam berkat kerendahan hatinya. Dengan kerendahan hati dan jiwa yang besar itu, Maria merasa berkewajiban untuk menghormati yang lebih Agung dari dirinya. Kerendahan hati itu juga yang membuat Maria menempatkan kehendak Ilahi dalam posisi paling penting atau paling utama dalam hidupnya. Terlaksanannya kehendak Allah menjadi perhatian yang paling penting dalam hidup Maria". ${ }^{42}$

Sejumlah unsur ketaatan yang dimiliki Maria menempatkannya bukan sekadar sebagai 'hamba Tuhan' sebagaimana yang lainnya di dalam Kitab Suci. Sebagai hamba Tuhan, Maria memiliki posisi yang unik, terutama dalam menghadirkan misteri dan rencana keselamatan Allah bagi manusia.

\section{KEUNIKAN MARIA SEBAGAI 'HAMBA TUHAN'}

Jaminan kehadiran Allah mendapat tanggapan dari Maria dengan seruannya yang sangat personal. Maria menyebut dirinya sebagai 'hamba Tuhan'. Tanggapannya itu

\footnotetext{
$42 \quad$ I. Biffi, Il si di Maria. La Madre di Dio nella teologia medioevale (Milano: Jaca Book, 2006) 66.
} 
memposisikan Maria sebagai hamba bukan berdasarkan kepentingan pribadinya secara manusiawi saja, melainkan berdasarkan iman dalam ketaatan penuh kepada kehendak Allah. ${ }^{43}$ Tanggapan Maria ini adalah yang ketiga dalam narasi kabar sukacita. Tanggapan pertama adalah yang muncul dalam keheningan reflektif sesaat setelah salam Malaikat Gabriel (Luk.1:29). Yang kedua adalah tanggapan dalam rupa permohonan penjelasan tentang pesan yang dibawa Gabriel (Luk.1:34). Dalam tanggapan yang ketiga ini Maria memberikan persetujuannya kepada rencana dan kehendak Allah (Luk.1:38). ${ }^{44}$

Tanggapan ketiga Maria ini terbagi menjadi dua. Pertama, Maria memandang dan menempatkan dirinya sendiri dengan menyebut bahwa ia adalah 'hamba Tuhan'. ${ }^{45}$ Kedua, Maria memberikan persetujuannya kepada rencana dan kehendak Allah. Dalam persetujuan bahwa dirinya adalah 'hamba Tuhan', Maria menyatakan penghormatan dan pengakuan penuh bahwa Allah adalah Tuhannya. Sekaligus dengan itu Maria mengungkapkan ketaatannya tak terbatas di bawah kehendak Allah. Dengan ketaatannya itu, Maria membuat dirinya tersedia untuk rencana dan kehendak Allah. ${ }^{46}$

Dengan menyatakan diri sebagai 'hamba Tuhan' dan mengungkapkan ‘jadilah padaku menurut perkataanmu itu', Maria menyatakan kesanggupannya menerima kehendak Allah. Ungkapan tersebut juga memasukkannya ke dalam golongan para 'hamba Tuhan' yang menjadi perantara

\footnotetext{
$43 \quad$ M. Thurian, Marie. Mère du Seigneur. Figure de l'Église (Paris: du Cerf, 1983) 89-103.

44 H. Schürmann, Das Lukasevangelium, 1. Teil, HThKNT (Freiburg; Basel; Wien, 1969) 57.

45 J. Ernst, Das Evangelium nach Lukas, RNT (Regensburg, 1976) 74.

46 A .Valentini, "L'annuncio a Maria," Theotokos 4 (1996), 281 295 (292-293).
}

keselamatan Allah bagi manusia. ${ }^{47}$ Kesanggupannya itu sekaligus menunjukkan persetujuannya pada kehendak Allah yang memilih dirinya sebagai pelaksana sabda sekaligus ibunda Putra Allah. Di atas segalanya, persetujuan Maria menjadi Bunda Allah merupakan buah penyerahan dirinya secara total kepada Allah yang terwujud secara konkret dalam keperawanannya. Maria menyerahkan dirinya secara total kepada Allah supaya dapat melayani dan melaksanakan rencana penyelamatan dari Yang Mahakuasa. ${ }^{48}$ Penyerahan diri Maria menjadi pintu masuk bagi Yesus untuk menjadi Mesias. Meskipun belum disebut dalam narasi, gelar itu menunjukkan bahwa Yesus itulah yang akan menjadi Juruselamat bagi umat manusia. ${ }^{49}$

Tanggapan semacam ini menjadi satu-satunya atau unik di antara semua ungkapan dalam Kitab Suci. ${ }^{50}$ Selain Maria, tidak ada perempuan lain dalam Kitab Suci yang menyebut dirinya sebagai 'hamba Tuhan' dalam menerima tugas perutusan Allah. Selain Maria, tidak ada ibu lain dalam Kitab Suci yang menanggapi informasi kelahiran puteranya dengan persetujuan atau identifikasi diri sebagai 'hamba Tuhan'. Sejumlah tokoh perempuan dalam Perjanjian Lama memang menyebut atau disebut sebagai 'hamba(-Mu) Tuhan. Mereka adalah Hagar (Kej.16:7-14; 17:1522), Sarai (Kej.18:9-15), Hana (Hak.13:223; 1Sam.1:11), dan Ester (Est.4:17). Dalam konteksnya masing-masing para

\footnotetext{
$47 \quad$ Paulus Seeanner, Eis aqui a serva do Senhor (LC 1,38). A autodesignação de Maria e seu fundo bíblico (5), https:// institutumsapientiae.files.wordpress.com/2017/02/sc-201602.pdf.

48 John Paul II, Redemptoris Mater. Mary: God's Yes to Man (San Francisco: Ignatius Press, 1987) 39.

49 Adela Yarbro Collins and John J. Collins, Son of God: Divine, Human and Angelic Messianic Figures in Biblical and Related Literature (Grand Rapids: Eerdmans, 2008) 71.

50 A.A. Rodríguez, "La vocacíon de María a la maternidad (LC 1,26-38)," Eph Mar 43 (2,93): 153-173 (171).
} 
perempuan itu menyebut diri mereka sebagai 'hamba(-Mu) Tuhan'. Akan tetapi, mereka mengindentifikasi diri mereka seperti itu dalam konteks berharap supaya permohonan mereka memeroleh jawaban karena situasi mereka saat itu nyaris tanpa harapan. Selain itu, konteks mereka saat itu juga bukanlah perutusan untuk melaksanakan suatu misi tertentu. Dengan memperhatikan alasan penyebutan diri sebagai 'hamba Tuhan' itu, tanggapan Maria ini adalah satu-satunya di dalam seluruh Kitab Suci yang menunjukkan bahwa ia siap melaksanakan tugas atau misi dari Allah.

Para nabi juga mendapat sebutan sebagai 'hamba Tuhan'. Misalnya, kitab nubuat Deutero-Yesaya (Yes.40-55) menggunakan 20 sebutan nabi sebagai 'hamba Tuhan'. Selain itu, dalam Proto-Yesaya (Yes.1-39), sebutan 'hamba Tuhan' untuk nabi juga ditemukan lima kali dalam bentuk tunggal maupunjamak. ${ }^{51}$ Akan tetapi, sebagai 'hamba Tuhan' nabi melaksanakan tugas pelayanan supaya tindakan Allah terlaksana bagi umatNya. Dengan kata lain, pelayanan mereka sebagai 'hamba Tuhan' terarah langsung kepada umat Allah. Dalam panggilan para nabi sebagai 'hamba Tuhan', Allah memilih hamba-Nya itu untuk membawa keadilan untuk umat manusia. Nabi atas nama Allah harus membawa kebebasan bagi yang diperbudak dan penglihatan bagi yang buta. ${ }^{52}$ Sedangkan pelayanan Maria langsung terarah kepada Putera-Nya, tidak langsung kepada umat Allah.

Selain keterarahannya yang langsung kepada Allah, yang membuat posisi Maria

\footnotetext{
51 Obielosi Dominic C., "The Concept of the Servant of God and Isaiah's Connection: A Politico-Theological Response to Recession," Academic Journal of Interdisciplinary Studies, Vol. 6, No. 2, July 2017: 93-102 (93).

52 M. Rosen, Y'shua. The Jewish Way to Jesus (Chicago: Moody Press, 1982) 97.
}

unik sebagai 'hamba Tuhan' adalah kedekatan relasinya dengan Allah yang memanggil dan mengutus. Selain Maria, tidak ada 'hamba Tuhan' lain yang mendapat panggilan sedemikian personal dan dekat dengan Allah sekaligus Putera-Nya. Kedekatan Maria dengan Allah sekaligus dengan Putera-Nya ini memberikan kepada Maria posisi unik. Dengan kedekatannya itu Maria dapat berpartisipasi secara aktif dalam karya penyelamatan baik dengan Allah maupun dengan Putera-Nya, karena Yesus adalah Putera Allah (Luk.1:35), sekaligus juga putra Maria (Luk.1:31).

Analisis menunjukkan bahwa unsurunsur ketaatan yang ditunjukkan Maria saat menanggapi kehendak Allah adalah ketaatan yang tanpa batas dan kepatuhan pada Allah sebagai satu-satunya pihak yang pantas dituruti. Dengan ketaatannya itu, Maria membuat dirinya tersedia untuk rencana dan kehendak Allah. Kesediaan diri itu bukan sekadar dalam kata-kata, melainkan sampai pada tindakan menyerahkan segala sesuatunya kepada kehendak Allah. Dengan kata lain, kehendak Allah menjadi prioritas satu-satunya Maria dalam bertindak. Oleh karena kehendak Allah menjadi satu-satunya prioritas Maria, setiap tindakan Maria senantiasa bertujuan memberi keuntungan kepada Allah. Selain itu, ketaatan Maria juga dilandasi relasi personal yang sangat dekat dengan Allah sekaligus dengan PuteraNya. Dengan kedekatannya itu Maria dapat berpartisipasi secara aktif dalam karya penyelamatan baik dengan Allah maupun dengan Putera-Nya.

\section{KETAATAN MARIA MENURUT LUMEN GENTIUM}

Iman Maria menemukan klimaks atau puncaknya dalam persetujuannya terhadap 
kehendak Allah. Ia mengimani Firman Allah yang disampaikan melalui Malaikat Gabriel. Tanggapan Maria menjadi tindakan iman yang dipersembahkan secara murni kepada Allah. Dengan hatinya murni itu, Maria menerima kehendak Allah baginya dan bagi dunia. ${ }^{53}$ Dengan tindakan imannya itu, Maria menjadi teladan iman bagi manusia. Tindakan imannya mirip dengan yang ditunjukkan Abraham saat mendapat panggilan menjadi bapa sejumlah besar bangsa (Kej.17:5-6). Sama seperti iman Abraham yang merupakan awal dari rencana keselamatan Allah dalam Perjanjian Lama, iman Maria dalam episode kabar sukacita menyatakan rencana keselamatan Allah dalam Perjanjian Baru. ${ }^{54}$ Iman Maria tidak hanya terungkap dalam tanggapannya terhadap kehendak Allah, tetapi juga dalam tindakannya mengasuh dan memelihara Putera Allah ${ }^{55}$ sebagai wujud memelihara dan mewujudnyatakan Firman Allah dalam tindakan konkret. Maria terlibat penuh dalam rencana keselamatan Allah dengan mengasuh dan memelihara Yesus. ${ }^{56}$ Sikap taat yang ditunjukkan Maria menjadi tanggapan dan sikap seluruh umat manusia..$^{57}$

Tanggapannya itu mengungkapkan kepercayaan diri sepenuhnya kepada kehendak Allah. Dengan persetujuan bebas dan penuh kesadaran Maria, ${ }^{58}$ Allah menjelma menjadi manusia dalam diri Putera-Nya, Yesus. Dalam hal ini, Allah menunjukkan bahwa Diri-Nya sungguh

\footnotetext{
53 James Hickey, Mary at the Foot of the Cross (San Francisco: Ignatius, 1988) 37.

54 John Paul II, op.cit., 14.

55 Salvatore Garofalo, Mary in the Bible (Milwaukee: The Bruce Publishing Company, 1961) 150.

56 Bertrand Buby, Mary: The Faithful Disciple (Mahwah: Paulist Press, 1985) 78.

57 Wilfried Stanissen, Maria Dalam Kitab Suci dan Dalam Hidup Kita (Malang: Dioma, 1985) 15-16.

58 Stefano de Fiores, Maria Madre di Gesù. Sintesi storicosalvifica (Bologna: Edizione Dehoniane, 1992) 221.
}

menganugerahkan kehendak bebas pada manusia untuk mengambil keputusan terkait persetujuannya pada kehendak Ilahi. Allah membutuhkan kehendak bebas dari ciptaan-Nya untuk memeroleh persetujuan untuk merealisasikan keselamatan-Nya. ${ }^{59}$ Dengan persetujuannya pada kehendak Allah, Maria membuka pintu rahmat Allah yang sebelumnya telah tertutup rapat akibat dosa Adam dan Hawa (Kej.3:124) yang menyatakan tidak pada rencana penyelamatan Allah.

Paulus mengkonfirmasi ketaatan Maria sebagai kebenaran dalam suratnya kepada jemaat Roma.

\begin{abstract}
"Sebab itu, sama seperti oleh satu pelanggaran semua orang beroleh penghukuman, demikian pula oleh satu perbuatan kebenaran semua orang beroleh pembenaran untuk hidup. Jadi sama seperti oleh ketidaktaatan satu orang semua orang telah menjadi orang berdosa, demikian pula oleh ketaatan satu orang semua orang menjadi orang benar" (Rom.5:18-19).
\end{abstract}

Ketaatan Maria terbukti dalam tanggapannya terhadap salam dari Malaikat Gabriel. Sikap taat itulah yang membuat Maria dipilih dan dipanggil Allah. ${ }^{60}$ Melalui ketaatan dan kerendahan hatinya dalam menerima kehendak Allah, Maria menunjukkan kerja samanya dengan Allah. Melalui tindak kerja samanya dengan Allah, Maria memposisikan dirinya sebagai model ketaatan bagi umat beriman dalam kehidupan sehari-hari. ${ }^{61}$ Posisi Maria sebagai model bagi umat beriman ditegaskan Gereja dalam

\footnotetext{
59 Joseph Cardinal Ratzinger and Hans Urs Von Balthasar, Mary: The Church at the Source, 89.

60 José Cristo Rey Gracía Paredes, Mary and the Reign of God (Quezon City, Philippines: Claretian Publications, 1988) 151 158.

61 George A. Maloney, Mary: The Womb of God (Denville, New Jersey: Dimension Books, 1976) 16.
} 
Konstitusi Dogmatis tentang Gereja 'Lumen Gentium'. Konstitusi ini mendedikasikan bagian akhirnya (53-69) untuk memberi penjelasan pandangan Gereja Katolik tentang Maria. Pandangan utama Lumen Gentium terhadap Maria menggemakan kembali permenungan Irenæus tentang Maria sebagai Hawa yang baru, persis karena jawaban 'Ya' yang disampaikannya terhadap kehendak Allah. Dengan kata lain, ketaatan Maria menjadi landasan bagi peran Maria sebagai model bagi umat beriman.

Secara khusus, dokumen Konsili Vatikan II ini menegaskan Maria sebagai model dalam perannya sebagai ibu orang beriman. Peran keibuan Maria dalam Gereja ini mendapat dua makna. Pertama, peran keibuannya sebagai Bunda Yesus Kristus, Putera Allah (LG 61). Kedua, peran keibuannya sebagai ibu rohani bagi umat beriman. Perannya yang kedua ini berada dalam ranah tata rahmat. Dalam tata rahmat, Maria menjadi ibu bagi umat beriman yang adalah saudara dan saudari Yesus Puteranya (LG 62). Peran Maria sebagai ibu rohani bagi umat beriman ini mendatangkan rahmat bagi mereka. Atas alasan tersebut umat beriman seharusnya tanpa ragu-ragu berusaha mendekatkan diri kepada Maria karena berkatnya, mereka dapat lebih dekat dengan Yesus, Putera Maria. Berdasarkan kesediaannya menjadi Bunda Yesus Kristus inilah Maria pantas berperan sebagai typos Gereja. Dalam hal ini typos bermakna model bagi umat beriman sebagai Gereja.

Secara khusus, dalam keteladanannya bersikap taat, Maria menunjukkan kesediaan dan pelayanan total kepada kehendak Allah. ${ }^{62}$ Sebagai manusia, Maria tidak luput dari kesulitan, tantangan dan risiko hidup.

José Cristo Rey Gracía Paredes, op.cit., 157.
Narasi 'kabar sukacita' melukiskan bahwa Maria harus berhadapan dengan misteri panggilannya sebagai Bunda Allah. Dalam panggilan itu Maria harus menanggung segala risiko hidup yang ia terima dari tawaran berpartisipasi dalam karya keselamatan Allah itu. Akan tetapi, Maria tetap taat dalam imannya. Walaupun sempat mengalami rasa bimbang dan ragu, ia berani memberikan persetujuan dan kesediaan untuk menjadi 'hamba Tuhan'. Atas dasar inilah Maria menjadi Bunda yang terberkati. Sebagaimana yang telah ditunjukkan Maria sebagai typos atau model hidup, umat beriman dalam pelbagai kesulitan hidup yang dialaminya harus tetap memiliki iman yang mantap. Menurut Santo Agustinus, "Kita akan melihat Allah dan Allah sendiri akan menjadi pandangan kita. Pandangan Allah itu akan menjadi hadiah iman". ${ }^{63}$

Sebagai orang Kristiani, umat beriman dipanggil untuk menempatkan Maria sebagai model hidup beriman. Menurut Lumen Gentium, penempatan itu berdasar pada peran keibuannya sebagai ibu rohani bagi umat beriman (LG 62). Sebagaimana seorang anak senantiasa mendapatkan teladan dari ibunya, demikian pula dengan menempatkan Maria sebagaiibu rohani, umat memeroleh petunjuk untuk menghidupi imannya dalam menghadapi aneka macam dinamika kehidupan. Secara khusus model hidup beriman yang diteladankan Maria itu adalah berserah diri kepada kehendak Allah dengan mengembangkan ketaatan dan kesediaan diri dalam iman walaupun untuk itu harus mengalami saat-saat yang membuat diri bimbang dan ragu. ${ }^{64}$

\footnotetext{
63 Matungulu Otene, To Be with Christ Chaste, Poor and Obedient (Kinshasa Afrika: St. Paul Publications, 1983) 72.

64 George A. Maloney, op.cit., 94.
} 


\section{PENUTUP}

Analisis atas narasi 'kabar sukacita' (Luk.1:26-38) mengungkapkan unsurunsur ketaatan yang dimiliki Maria saat menanggapi kehendak Allah. Ketaatan Maria adalah ketaatan yang tanpa batas dan kepatuhan pada Allah sebagai satusatunya pihak yang pantas dituruti. Dengan ketaatannya itu, Maria membuat dirinya tersedia untuk rencana dan kehendak Allah. Kesediaan diri itu bukan sekadar dalam kata-kata, melainkan sampai pada tindakan menyerahkan segala sesuatunya kepada kehendak Allah. Dengan kata lain, kehendak Allah menjadi prioritas satu-satunya Maria dalam bertindak. Oleh karena kehendak Allah menjadi satu-satunya prioritas Maria, setiap tindakan Maria senantiasa bertujuan memberi keuntungan kepada Allah. Selain itu, ketaatan Maria juga dilandasi relasi personal yang sangat dekat dengan Allah sekaligus dengan Putera-Nya. Dengan kedekatannya itu Maria dapat berpartisipasi secara aktif dalam karya penyelamatan baik dengan Allah maupun dengan Putera-Nya.

Dalam analisis atas peran Maria, terutama dalam narasi 'kabar sukacita' (Luk.1:26-38) dan Konstitusi Dogmatis tentang Gereja 'Lumen Gentium', menjadi jelas bahwa Maria memiliki posisi yang kuat dalam kehidupan setiap orang Kristen, terutama sebagai ibu rohani. Allah telah memberi umat beriman Maria sebagai model orang Kristen yang sempurna. Melalui kerjasama dan partisipasi aktifnya dengan kehendak Allah, Maria berdiri sebagai model bagi kehidupan Kristiani. ${ }^{65}$ Umat beriman menjadi Kristiani hari ini berkat ungkapan 'ya' dari Maria yang total kepada Allah. Mengetahui bahwa Allah sedang mencari jalan masuk ke dalam hatinya, Maria secara terus-menerus menyerahkan hidupnya pada rancangan suci Allah. Dalam peristiwa 'kabar sukacita' Maria menyambut kehadiran Allah ke dalam dirinya. Sambutannya menunjukkan bahwa manusia sepenuhnya dapat diubah Allah. Maria menjadi gambaran jiwa yang menerima kuasa Roh Kudus untuk menghadirkan Allah dalam kehidupan nyata. ${ }^{66}$

Ketaatan Maria menjadi model ideal umat beriman. Dengan mengikuti dan meneladan ketaatan Maria, umat beriman dapat mendekatkan relasinya dengan Allah. Dengan mendekatkan relasinya dengan Allah, seperti Maria, umat beriman dapat semakin mengenali dan memahami rencana dan kehendak Allah dalam diri mereka. Pada gilirannya, pemahaman tersebut mendorong umat beriman untuk menyediakan dirinya bagi tata keselamatan Allah yang ditujukan bagi semakin banyak orang.

\footnotetext{
65 George A. Maloney, op.cit., 16.

66 Frédéric Manns, Beata Lei che ha creduto. Maria, una donna ebrea (Milano: Edizioni Terra Santa, 2009) 146.
} 


\section{DAFTAR RUJUKAN}

Álvarez, C.G. María Discípula de Jesús, y mensajera del Evangelio. Bogotá, Colombia: San Pablo. 2007.

Bar-Efrat, Shimon. Narrative Art of Bible. Sheffield: Sheffield Academic Press, 1997.

Benedict XVI. Maria: On the Mother of God. San Francisco: Ignatius Press, 2009.

Biffi, I. Il sì di Maria. La Madre di Dio nella teologia medioevale. Milano: Jaca Book, 2006.

Brown, William. The Tabernacle: Its Priests and Its Services. Peabody, Massachusetts: Hendrickson Publishers, 1996.

Buby, Bertrand. Mary: The Faithful Disciple. Mahwah: Paulist Press, 1985.

Bultmann, Rudolf. History of the Synoptic Tradition. trans. John Marsh. Oxford: Basil Blackwell, 1963.

Bur, Jacques. How to Understand the Virgin Mary. London: SCM Press LTD, 1994.

Buzzetti, Carlo. Dizionario Base del Nuovo Testamento. Greco-Italiano. Roma: Società Biblica Britannica e Forrestiera, 2001.

Collins, Adela Yarbro and Collins, John J. Son of God: Divine, Human and Angelic Messianic Figures in Biblical and Related Literature. Grand Rapids: Eerdmans, 2008.

de Fiores, Stefano. Maria Madre di Gesù. Sintesi storico-salvifica. Bologna: Edizione Dehoniane, 1992.

de La Potterie, Ignace. Mary in the Mystery of the Covenant. New York: Alba House, 1992.

Deiss, Lucien. Mary: Daughter of Sion. Collegeville, Minn: Liturgical Press, 1972.

Dominic C., Obielosi. "The Concept of the Servant of God and Isaiah's Connection: A Politico-Theological Response to Recession." Academic Journal of Interdisciplinary Studies, Vol. 6, No. 2, July 2017: 93-102.

Donnelly, Philip J. "The Perpetual Virginity of the Mother of God." Ed. Juniper B. Carol. Mariology vol. 2. Milwaukee: The Bruce Publishing Company, 1957.

Ernst, J. Das Evangelium nach Lukas, RNT. Regensburg, 1976.
Fitzmyer, Joseph A. The Gospel According to Luke I-IX . AB 28. Garden City: Doubleday, 1981.

Galot, Jean. Mary in the Gospel. Westminster, Maryland: The Newman Press, 1965.

Garofalo, Salvatore. Mary in the Bible. Milwaukee: The Bruce Publishing Company, 1961.

González, José María Salvador. "The Virgin Mary as a Model of Obedience in the Patristic Tradition and Her Representation in the Late Medieval Iconography of the Annunciation." Social Sciences and Humanities Journal (SSHJ), Vol. 10, No. 8, August 2015: 1-23.

Grassy, Joseph A. Mary. Mother and Disciple: From the Scripture to the Council of Ephesus. Delaware: Michael Glazier, Inc. 1988.

Green, Joel B. "The Social Status of Mary in Luke 1,5-2,52: A Plea for Methodological Integration." Biblica 73 (1992): 458-471.

Harris, Ralph W. Old Testament Types. Springfield, MO.: Gospel Publishing House, 1965.

Hickey, James. Mary at the Foot of the Cross. San Francisco: Ignatius, 1988.

Komisi Kitab Suci Kepausan. Penafsiran Alkitab dalam Gereja. Yogyakarta: Kanisius, 2003.

Kristiyanto, Eddy. Maria dalam Gereja. Yogyakarta: Kanisius, 1987.

Jacobs, Tom. Lukas. Pelukis Hidup Yesus. Yogyakarta: Kanisius, 2006.

John Paul II. Redemptoris Mater. Mary: God's Yes to Man. San Francisco: Ignatius Press, 1987.

Johnson, Elizabeth A. Dangerous Memories: A Mosaic of Mary in Scripture: Drawn from Truly Our Sister. New York; London: Continuum, 2006.

Leon-Dufour, Xavier. Dizionario di Teologia Biblica. Genova: Casa Editrice Marietti S.p.A., 2002.

Leonhard, Goppelt. Typos. The Typological Interpretation of the Old Testament in the New. Grand Rapids, MI.: Wm. B. Eerdmans Publishing Co., 1939.

Maloney, George A. Mary: The Womb of God. Denville, New Jersey: Dimension Books, 1976. 
Manns, Frédéric. Beata Lei che ha creduto. Maria, una donna ebrea. Milano: Edizioni Terra Santa, 2009.

Marguerat, Daniel and Bourquin, Yvan. How to Read Bible Stories. An Introduction to Narrative Criticism . London: SCM Press, 1999.

Marshall, I.H. The Gospel of Luke: A Commentary on the Greek Text. Exeter: Paternoster; Grand Rapids: Eerdmans, 1978.

McHugh, John. The Mother of Jesus in the New Testament. New York: Doubleday, 1975.

Otene, Matungulu. To Be with Christ Chaste, Poor and Obedient. Kinshasa Afrika: St. Paul Publications, 1983.

Paredes, José Cristo Rey Gracía. Mary and the Reign of God. Quezon City, Philippines: Claretian Publications, 1988.

Puerto, M. Navarro. María, la mujer. Ensayo psicológico bíblico. Madrid: Claretianas, 1987.

Ratzinger, Joseph Cardinal. Daughter Zion: Meditations on the Church's Marian Belief. trans. John M. McDermott SJ. San Francisco: Ignatius Press, 1983.

Ratzinger, Joseph Cardinal and von Balthasar, Hans Urs. Mary: The Church at the Source. San Francisco: Ignatius Press, 2005.

Reid, B.E. "An Overture to the Gospel of Luke." Theology and Mission 39,6 (2012): 428-434.

Rodríguez, A.A. "La vocacíon de María a la maternidad (Lc 1,26-38)." Eph Mar 43 (2,93): 153-173.

Rosen, M. Y'shua. The Jewish Way to Jesus. Chicago: Moody Press, 1982.

Rusconi, Carlo. Vocabolario del Greco del Nuovo Testamento. Bologna: Edizione Dehoniane, 1997.

Schauss, Hayyim. The Lifetime of a Jew Throughout the Ages of Jewish History. New York: Union of American Hebrew Congregations, 1950.
Schechter, Solomon. Blau, Ludwig and Hirsch,

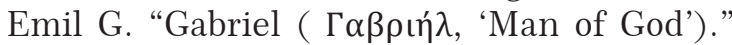
Jewish Encyclopedia. New York; London: Funk and Wagnalls Company, 1901.

Scheffcyk, Leo. Maria, Crocevia della fede cattolica. Pregassona, Lugano: Eupress, 2002.

Schürmann, H. Das Lukasevangelium, 1. Teil, HThKNT. Freiburg; Basel; Wien, 1969.

Seeanner, Paulus. Eis aqui a serva do Senhor (Lc 1,38). A autodesignação de Maria e seu fundo bíblico (5), https://institutumsapientiae.files. wordpress.com/2017/02/sc-2016-02.pdf.

Sitompul, A.A. dan Beyer, U. Metode Penafsiran Alkitab. Jakarta: BPK Gunung Mulia, 1973.

Spicq, Ceslas. Theological Lexicon of the New Testament. trans. James D. Ernest. Peabody, Massachusetts, 1994.

Stanissen, Wilfried. Maria Dalam Kitab Suci dan Dalam Hidup Kita. Malang: Dioma, 1985.

Thurian, M. Marie. Mère du Seigneur. Figure de l'Église. Paris: du Cerf, 1983.

Valentini, A . "Lannuncio a Maria," Theotokos 4 (1996), 281-295.

Weinandy, Thomas G. Jesus Becoming Jesus: A Theological Interpretation of the Synoptic Gospels. Washington, D.C: Catholic University of America Press, 2018.

Welzen, Huub. "Exegetical Analysis and Spiritual Readings of the Story of the Annunciation (Luke 1:26-38)." Acta Theologica Supplementum 15, 2011: 21-36.

Zerwick, Max and Grosvenor, Mary. A Grammatical Analysis of the New Testament. Roma: Editrice Pontificio Istituto Biblico, 1996. 